Saudi Journal of Medical and Pharmaceutical Sciences

Abbreviated Key Title: Saudi J Med Pharm Sci ISSN 2413-4929 (Print) |ISSN 2413-4910 (Online) Scholars Middle East Publishers, Dubai, United Arab Emirates Journal homepage: http://scholarsmepub.com/sjmps/

Review Article

\title{
Review on Potential Herb Wild Poinsettia
}

S. Arunkumar ${ }^{1}$, P. Meenaprabha ${ }^{2 *}$ and V. Kamalakannan ${ }^{3}$

${ }^{1}$ Student, JKK Nattraja College of Pharmacy, Kumarapalayam, Namakkal, Tamilnadu, India

${ }^{2}$ Associate Professor, Department of Pharmacognosy, JKK Nattraja College of Pharmacy, Kumarapalayam, Namakkal, Tamilnadu, India

${ }^{3}$ Professor, Department of Pharmaceutics, JKK Nattraja College of Pharmacy, Kumarapalayam, Namakkal, Tamilnadu, India

DOI: $10.36348 /$ sjmps.2019.v05i12.016

| Received: 19.12.2019 | Accepted: 26.12.2019 | Published: 30.12 .2019

*Corresponding author: P. Meenaprabha

\section{Abstract}

Euphorbia cyathophora Linn (Euphorbiaceae) is commonly known as Wild poinsettia, fireplant, fire on the mountain, milkweed, widely used for the treatment of constipation, bacterial and inflammatory disease conditions like arthritis and rheumatism. Colourful plants are very dangerous like Daffodil, Lantana, Foxglove and such plants are conserved as a genetic resource and used as food, fibre, fertilizer, fuel and in used in diversely way. Euphorbia cyathophora is one such plant. This review highlights the systematic position, vernacular names, vegetative characters, ecology and distribution, phytochemistry and the economical values of the Euphorbia cyathophora are well discussed.

Keywords: Euphorbia cyathophora, dwarf poinsettia, painted leaves, Wild poinsettia, Medicinal Properties. Reddish leaves, Anti-asthma.

Copyright @ 2019: This is an open-access article distributed under the terms of the Creative Commons Attribution license which permits unrestricted use, distribution, and reproduction in any medium for non-commercial use (NonCommercial, or CC-BY-NC) provided the original author and source are credited.

\section{INTRODUCTION}

Euphorbia cyathophora L., also known as Catalina $[1,2]$ dwarf poinsettia, fire on-the-mountain, and painted leaf [3, 4], wild poinsettia, is a highly competitive non-cultivable weed responsible for great agricultural losses in abundant crops such as soybean and corn [5, 6]. Euphorbia cyathophora, belongs to Euphorbiaceae or Spurge Family which includes blooming 300 genera and about 7,500 species [7, 8].
This is non-cultivable weed mostly seen in North America, South America, Australia and grown also naturalized in tropical, sub-tropical, and warmer area elsewhere. Here, the in florescence axis is convex and it have attractive reddish colored floral leaves. The plant traditionally used for stomach ache, treat constipation, expel intestinal worms [9]. The systematic position, vernacular names, vegetative characters of the plant are given in the following table [1-3].

Table-1: Natural Description [10]

\begin{tabular}{|l|l|}
\hline Kingdom & Plantae \\
\hline Class & Dicotyledonae \\
\hline Sub-Class & Monochlamydeae \\
\hline Order & Malpighiales \\
\hline Family & Euphorbiaceae \\
\hline Genus & Euphorbia \\
\hline Species & Cyathophora \\
\hline
\end{tabular}


P. Meenaprabha et al; Saudi J Med Pharm Sci, Dec., 2019; 5(12): 1114-1119

Table-2: Natural Description

\begin{tabular}{|l|l|}
\hline Description & Annual, Perenial \\
\hline Duration & Herb \\
\hline Habitat & 1 -3 ft \\
\hline Size & $\begin{array}{l}\text { Alternate, Oblanceolate, glabrous, Smooth texture, Entire Margins, the upper or bracteal leaves } \\
\text { habitually red, Concerning the base }\end{array}$ \\
\hline Leaves & $\begin{array}{l}\text { Monoecious Minute, in cathia, involucres glabous, perianth absent; staminate flowers local aroung } \\
\text { one female flower; Female flowers terminal, styles }\end{array}$ \\
\hline Flowers & Yellow, Green \\
\hline Flower Colour & Cyathium \\
\hline Inflorescence & Short, erect, and herb, Grown in marshy region woith have adequate sunlight. \\
\hline Habitat & $\begin{array}{l}\text { Oviod-cyclindrical, terminate with truncate or rounded, surface tuberculate, ecarunculate; black n } \\
\text { colour; produces 4500 per plant beset season; lack dormancy; not light sensitive }\end{array}$ \\
\hline Seeds & Smooth, green, erect, lateral, glabrous, pilose, causitic milky sap \\
\hline Stem & Simple, alternate, petiolate, elliptic, ovate, lanceolate, acute apex, rulate, oblong, short stalk. \\
\hline Leaves &
\end{tabular}

\section{THE CHIEF FEATURES: DISTINGUISHING FEATURES}

1. These species have milky sap often seen, when cut stems and leaves.

2. The leaves are often fiddle-shaped and are common oppositely arranged in the stems.

3. The leaves fair under the 'flowers' have reddish-pink coloured bases (i.e. they look as to be painted') and can undoubtedly be mistaken for large petals at a distance.

4. It have attracting attention green colour 'flowers' are travel at the edge of the branches.

5. A Short life-span herbaceous plant which subsidiary $1 \mathrm{~m}$ tall [11].

\section{HISTROY}

The genus name, Euphorbia, was derived from the Greek physician Euphorbus, of King Juba II on Numidia. The species name, cyathophora, make out from two Greek terms for 'cup-bearer' and refer to the cup-shaped base of the flower containing the glands. The author name for this plant classification, 'Murray' preferred to Johan Andreas Murray (1740-1791), Swedish physician who investigated and published on plant make out medicines. His most important work was Publish the book with have 6 volume Apparatus medicaminum [12].

\section{The Geographical Distribution}

This species has a broad, distribution through Australia. It is often seen in costal districts of queensland and northern new south wales, randomly in the northern territory and in the northern and western parts of Western Australia, and present in the coastal districts of central new south wales and then rationalized on several offshore islands (i.e. Lord Howe Island, Christmas Island, Norfolk Island, the Cocos Islands and the Coral Sea Islands) and sparingly naturalized on the Eyre Peninsula in South Australia. In India, salem, dindugal placed in tamilnadu, kapurthal, jalandhar, nawanthahar, hoshiarpur placed in punjab, gu jarat [13]. Autauga, baldwin, butler, calhoun, coffee, covington, crenshaw, dale, etowah, franklin, henry, houston, lawrence, madison, mobile, montgomery, morgan, pike in Alabama [14] and naturalized on numerous pacific islands like fiji, french polynesia, guam, hawaii, kiribati, the marshall islands, nauru, new caledonia, niue, palau and wake island.

\section{HARVESTING PROBLEM}

After seeding the adult plants remain green in the crop stand for 60-80 days [15] and cause serious problems during harvesting [16, 17]. In common with all Euphorbiaceae member, E heterophylla contains a high sticky white latex, not strictly poisonous but dirt and vegetation to adhere, reduce quantity and reduce quality of crop.

\section{PHYTOCHEMICAL CONSTITUENTS}

Euphorbia cyatophora have essential oil like phellandrene, alpha-Pinene, Camphene, Sabinene, BetaPinene, Limionene, 1,8-Cineole, Linalool, trans-Pinocarveol, Myrtenal, Alloaromadenderene, satriven, Guaiazulene, Beta-Elemene, alpha-Elemene, endo-borneol, muretenal, sativen, Terpinene, cisThujopsene, Caryophyllene oxide, widdrolhydroxyether, Kikkanol A, Hexahydrofar- nesyl acetone, Kaur-16-one, 2,6,10- Trimethyltetrade- cane, n-Pentatriaconotane, nDocosane, n-Hexacosane, n-Triacontane, 4H-Chromene, 4a,5,6,7,8,8-a-hexahydro- 2,3,5,5,8a-pentamethyl, nOctadecyl chloride [18]. Cyclo- hexasiloxane, dodecamethyl, Cyclononasiloxane, octade-camethyl, Hexadecanoic acid, methyl ester, Octadecanoic acid, methyl ester, 13-Docosenamidfe, Tetradecamethylheptasiloxane, $\quad 1,3,5,7,9,11,13,15$ hexadecamethyloctasiloxane, Hexadecanoic acid or palmitic acid methyl ester, Octade- canoic acid or stearic acid ester, Heptadecanoic acid or mar- garic acid, methyl ester,13-Docosenamide, Stigmasterol,2Cyclohexen-1-1one,4-(3-hydroxybutyl)-3,5,5-trimethyl, Cyclohexanone, 2-(1-methyl-2-nitroethyl)-, Quercetin 7,3',4'-trimethoxy, HAHNFETT, 2Ethylthio-2-etho xy-3- oxo-N-phenyulbutanamide [19]. 
Table-3: Phytochemical Components of Euphorbia Cyathophora discuss in following [20]

\begin{tabular}{|l|l|l|l|l|l|}
\hline Sl. No. & Class of Compounds & Flower & Stem & Root & Test Performed \\
\hline 01. & Alkaloids[Except leaves] & + & + & + & Mayer's test, Dragendorff's test \\
\hline 02. & Carbohydrates & + & + & + & Molish test, Fehling test. \\
\hline 03. & Phenolic Compounds & + & + & + & Ferric Chloride test \\
\hline 04. & Proteins and aminoacids & + & + & + & Xantho-protein test \\
\hline 05. & Vitamin C & + & + & + & Vitamin test \\
\hline 06. & Flavaniods & + & + & + & Ammonia test \\
\hline 07. & Sapoinins & + & + & + & With Sodium Carbonate \\
\hline 08. & Sterols & + & + & + & $\begin{array}{l}\text { Liebermann-Burchard test, Salklaow skin reaction, } \\
\text { Hesse's reaction }\end{array}$ \\
\hline 09. & Acid Compounds & + & + & + & With NaCO ${ }_{3}+\mathrm{H}_{2}$ (with litmus paper \\
\hline 10. & Terpenoids & + & + & + & $\begin{array}{l}\text { Plant extract }+ \text { Chloroform }+ \text { Sulphuric acid results in } \\
\text { brown colour. }\end{array}$ \\
\hline 11. & Oils & + & + & + & \\
\hline 12. & Peroxides & - & - & - & Potassium iodide test \\
\hline 13. & Polyuronids & - & - & - & Haemtoxylin test \\
\hline
\end{tabular}

\section{MEDICINAL PROPERTIES}

Table-4: Medicinal properties and uses of Euphorbia cyatophora linn. are explained

\begin{tabular}{|c|c|c|}
\hline Sl. No & Medicinal Properties & Reference \\
\hline 01. & Anti-Oxidant & {$[21-23]$} \\
\hline 02. & Hepato-Protective & [24] \\
\hline 03. & Anti-Microbia & {$[25,26]$} \\
\hline 04. & Fibrinogen Activity & [26] \\
\hline 05. & Anti-Diabetic Activity & {$[2]$} \\
\hline 06. & Anti-Cancer Activity & {$[1,17]$} \\
\hline 08. & Anti- Bacterial Activity & [27-29] \\
\hline 09. & Anti-inflammatory Activity & {$[22,30]$} \\
\hline 10. & Laxative Activity & [31] \\
\hline 11. & Analgestic Activity & [32] \\
\hline 12. & Cycloxygenase inhibitor & {$[30,32]$} \\
\hline 13. & Antinociceptive Activity & {$[20,32]$} \\
\hline 14. & Anti-viral Activity & {$[3,4,31]$} \\
\hline 15. & Alleopathic Activity & {$[20,23]$} \\
\hline 16. & Pesticide & {$[4,33,34]$} \\
\hline 17. & Insecticide & {$[4,33,34]$} \\
\hline 18. & Purgative Action & {$[35,36]$} \\
\hline 19. & Cytotoxity & {$[19,3]$} \\
\hline 20. & Anti-tumour Activity & {$[37,38]$} \\
\hline 21. & Anti-Cholinergic Activity & {$[30]$} \\
\hline 22. & Anti-Fungal Activity & {$[4,2,18]$} \\
\hline 23. & Anti-Listeria Activity & {$[4,2,18]$} \\
\hline 24. & Insect repellent & {$[4,33,34]$} \\
\hline 25. & GABA Benzodiazepine Receptors & {$[39,40]$} \\
\hline 26. & Counter Irritant & {$[41,42]$} \\
\hline 27. & Smoothening Agent & [42] \\
\hline 28. & 5-Alpha Reductase Inhibitor & {$[28,32,43]$} \\
\hline 29. & Anti-Androgenic effect & {$[24,28]$} \\
\hline 30. & Anti-Gout Activity & [44] \\
\hline 31. & Arachidonic acid inhibitor & [45] \\
\hline 32. & Precursor of Vitamin $\mathrm{D}_{3}$ & {$[46,52]$} \\
\hline 33. & Endocrine Protective & [24] \\
\hline 34. & Trypanosidal Activity & {$[19,52]$} \\
\hline 35. & Urinary Acidulant & [47] \\
\hline 36. & Entero Stimulant & {$[48,49]$} \\
\hline 37. & Methyl guanidine inhibitor & [49] \\
\hline 38. & Organogenesis & {$[50,52]$} \\
\hline 39. & Anti-Asthma Activity & {$[3,32,38,41,51]$} \\
\hline 40. & Mild Anti-Spasmodic Activity & {$[30,41]$} \\
\hline
\end{tabular}




\section{CONCLUSION}

The Plant E uphorbia cyathophora $L$. is a plant with numerous medicinal principles and other economic uses with the following features: a herb, pass round in the tropical and sub- tropical areas, growing in all types of soils and environmental conditions, not need to cultivation practices. The quality and quantity of the active principle which have significant for many ailments are subjected to many factors affecting growth such as climate, soil, etc. In marked standardization of the phytochemicals by these factors are very important to establish the uses of the plant more effectively.

\section{ACKNOWLEDGMENT}

Authors are grateful to Prof. Vijayabaskaran. M, Head of the Department, Department of Pharmacognosy, JKK Nattraja College of Pharmacy, Tamilnadu Jodhpur for the logistic support. Thanks are due to Dr. Sambath Kumar. R, Principal, JKK Nattraja College of Pharmacy, Tamilnadu for their help in the field.

\section{REFERENCES}

1. Lotha, R., Sivasubramanian, A., \& Muthuraman, M. S. (2018). Silver nanoparticles from medicinally important Euphorbia cyathophora extract: biosynthesis, characterization, and anticancer activity. Asian Journal Pharm Clin Res, 11(2):154156.

2. Annapurna, A., \& Hatware, K. (2014). Effect of aqueous extract of Euphorbia heterophylla on blood glucose levels of alloxan induced diabetic rats. Int. J. Res. Pharm. Chem, 4, 669-672.

3. Adedayin, B., \& Okenlyi, S. D. (2013). Cytotoxicity, antioxidant and antimicrobial activities of essential oil extracted from Euphorbia Heterophylla plant. Top class Journal of Herbal Medicine, 2(5):84-89.

4. Noura, S., \& Dosoky, N. (2018). Chemical Composition and Biological Activities of Essential Oils of Curcuma Species. Nutrients, 10(9):1-44.

5. Turner, I. M. (1999). Euphorbia heterophylla and E. cyathophora (Euphorbiaceae) in the Malay Peninsula. The Gardens bulletin, Singapore, 51(4):99-102.

6. Cerdeira, A. L., \& Gazziero, D. L. (2011). Agricultural impacts of glyphosate-resistant soybean cultivation in South America. J Agric Food Chem, 59(11): 5799-5807.

7. Chacalis, D. (2015). Wild poinsettia (Euphorbia heterophylla): an emerging weed in cotton and processing tomato in Greece. Hellenic Plant Prot $J, 8(1): 27-32$.

8. Wurdack, J., \& Hoffmann, P. (2005). Molecular phylogenetic analysis of uniovulate Euphorbiaceae (Euphorbiaceae sensustricto) using plastid RBCL and TRNL- FDNA sequences. American Journal of Botany, 92(8):1397-1420.

9. Erden, Y. S., Ekrem, H., \& Gisho, T. (1999).
Traditional medicine in Turkey IX, folk medicine in North West Anatolia. J.ethnopharmacol, 64:201-201.

10. Mangolin, A., \& Rubem, S. (2009). Esterase Polymorphism for Analysis of Genetic Diversity and Structure of Wild Poinsettia (Euphorbia heterophylla) Populations. Weed Science Society of America, 57(1):54-60.

11. Wilson, A. K. (1981). Euphorbia heterophylla: a Review of Distribution, Importance and Control. Tropical Pest Management, 27(1):32-38.

12. Lohr, M. T. L., \& Lohr, C. A. L. (2016). Euphorbia cyathophora, Weeds on Western Australia's Islands: A historical database with record spanning from 1913 to 2014, Version 1.

13. Euphorbia cyathophora - Indian Biodiversity Portal. (2019). Retrieved from 12/12/2019, from https://indiabiodiversity.org/species/show/266504.

14. Euphorbia cyathophora in Alabama Plant atlas. (2011). Retrieved from 12/12/2019, from http://www.floraofalabama.org/SpecimenDetails.a spx?PlantID=1827

15. Kinwa, O. M., Akinyemiju, O. A. (1990). Control of Euphorbia heterophylla L. in cowpea with herbicides and herbicide mixtures. Crop Protection, 9(3): 218-224.

16. Strobel, A., \& Nachmias, A. V. I. (1989). Agvobactevium rhizogenes Promotes the Initial Growth of Bare Root Stock Almond. Journal of General Microbiology, 131:1245-1249.

17. Manikandarajan, P. A., \& Sathish, M. (2018). Isolation, Characterization, Docking and AntiCancer Activity of Quercetin from Leaves of Euphorbia heterophylla linn. Int J Pharm Sci Res, 9(1):197-202.

18. Elshamy, A. I., \& AElgawad, A. M. (2019). Chemical Characterization of Euphorbia heterophylla L. Essential Oils and Their Antioxidant Activity and Allelopathic Potential on Cenchrusechinatus L. Chem Biodivers.,16(5):1-4.

19. Shaik, A. (2017). Phytochemical Composition of Euphorbia Heterophylla. International Journal of Advanced Life Sciences, 10(4):247-257.

20. Silva, U. P., \& Furlani, G. M. (2018). Allelopathic activity and chemical constituents of extracts from roots of Euphorbia heterophylla L. Nat Prod Res, 1(1):1-4.

21. Keerthana, K., \& Sridharan, G. (2014). Preliminary phytochemical screening and In vitro Anti- oxidant potential of Euphorbia Hetrophylla L. Int J Pharm Sci 6(8): 549-553.

22. Azoui, I., \& Frah, N. (2016). Insecticidal Effect of Euphorbia bupleurodies Latex on Blattela germanica. International journal of pure and applied zoology, 4(3):271-272.

23. Okeniyi, S. D., \& Adedoyin, B. J. (2012). Phytohemical screening, cytotoxity, antioxidant and antimicrobial activities of stem and leave extract of Euphorbia hetrophylla. Bulletin of 
Environment, Pharmacology and life science, 1(8):87-91.

24. Chitra, M., \& Sentilkumar, N. (2013). Hepatoprotective and antioxidant activity of Euphorbia cyathophora, International journal of Research in Pharmacology and Pharmacotherapeutics, 2(3):483-490.

25. Kirbag, S., \& Erecevit, P. (2013). Antimicrobial activities of some Euphorbia Species. African Journal Tradit Compliment AL- tern Med., 10(5):305-409.

26. Ahmed, M., \& Yousaf, M. (2016). Studies on wound healing activity of some Euphorbia Species on Experimental Rats. African Journal tradit Complemant Altern Med., 13(5):145-152.

27. Ughachukwu, P. O., \& Ezenyeaky, C. C. T. (2014). Evaluation of antibacterial activities of Euphorbia heterophylla. ISOR Journal of Dental and Medical Science. 13(11):69-75.

28. Vigneshwari, A., \& Abirami, S. (2018). Evaluation of in viro anti diabetic activity of various extracts of Euphorbia cyathophora. World Journal of Pharmacy and Pharamaceutical Science, 7(2):968-977.

29. Anilkumar, M. (2010). Ethnomedicinal plants as anti-inflammatory and analgesic agents. Ethonomedicine: A Source of Complemantary Therapeutics, 267-293.

30. Esmail, A., \& Snafi, A. (2010). Pharmacology and therapeutic potential of Euphorbia cyathospora- A review. ISOR Journal of Pharmacy, 7(1):7-20.

31. Paulinus, O., N., \& Abiodun, F. (2015). Effect if Aqueous leaf extract of Euphorbia heterophylla on Kidney, Liver and Pancreatic functions and plasma electrolytes in rabbits. Journal of Pharmaceutical and scientific innovation, 4(2):116-119.

32. Magalhaes, B., \& Riva, R. (2010). In vivo antiinflammatory action of eugenol on liposaccharideinduced lung injury. Journal Appl Physiol, 108:845-851.

33. Li, Y., \& Qin, Y. (2013). Studies on insecticidal acrrivites and action mechanism of noval benzoylphenylurea Candidate NK-17. PloS ONE, 8(6):1-13.

34. Oloninefa, S., D., \& Abalaka, M., E. (2018). A Phytochemicla screening and antibacterial susceptibility of wholeplant of Euphorbia Heterophylla crude extracts against selected against selected bacteria pathogens. Bayero Journal of Pure and Applied Sciences, 11(1):211220.

35. Onoja, O., \& Madibiole, K. (2015). Investigation of the laxative activity of Operculina turpethum extract in mice. International journal of Pharmaceutical and Clinical Research, 7(4):275279.

36. Loziene, K., \& Svediene, J. (2018). Influence of plant origin natural alpha pinene with different enantiomeric composition on bacteria, yeast and fungi. Fitoterapia, 127;20-24.

37. Oloninefa, S., D., \& Abalaka, M., E. (2018). Phytochemical screening and antibacterial susceptibility of whole plant of Euphorbia heterophylla crude extracts against selected bacteria pathogens. 11(1):211-220.

38. Chen, M., \& Zhang, Z. (2012). Anti Lung-Cancer activity and liposome-Based delivery sytems of beta-Element, Evid Based Complement Alternat Med., 23-27.

39. Yang, H., \& Woo, J. (2016). Alpha-Pinene, a Major constituent of pine tree Oils, Enhances nonrapid eye movement sleep in mice through GABA-Benzodiazepines receptors. Mol Pharmacol. 90(5):530-539.

40. Falodun, A., \& Agbakwuru, E. O. P. (2004). Phytochemical analysis and laxative activity of the leaf extracts of Euphobia heterophylla linn (euphorbiaceae). Pak. J. Sci. Ind. Res, 47(5), 345348.

41. Mahumoudvand, H., Sheibani, V., \& Keshavarz, S. (2016). Acetylcholinesterase inhibitor improves learning and memory impairment induced by toxoplasma gondii infection. Iranian Journal of Parasitology, 11(2):177-185.

42. Cyclohexasiloxane, dodecamethyl have smoothening activity (2019). Retrieved from $12 / 12 / 2019$, from https://pubchem.ncbi.nlm.nih.gov/compound/Cycl ohexasiloxane_-decamethyl,

43. Yuebin, G., \& Zhang, F. (2015). In vivo evaluation of the antiasthmatic, antitussive and expectorant activities and chemical components of three elaeagnus Leaves. Evid Based Complement Alternat Med, 1-7.

44. Kumar, S., Malhotra, R., \& Kumar, D. (2010). Euphorbia hirta: Its chemistry, traditional and medicinal uses, and pharmacological activities. Pharmacognosy reviews, 4(7), 58-61.

45. Osama, H., \& Narumiya, S. (1983). Inhibition of brain prostaglandin $\mathrm{D}$ synthetase and prostaglandin D2 dehydorgenase by some saturated and unsaturated fatty acids. Biochim Biophys Acta, 752(2):251-258.

46. Falodun, A., \& Okunrobo, L., O. (2006). Phytochemical screening and anti inflammatory evaluation of methanolic and aqueous extracts of Euphorbia heterophylla linn, African Journal of Biotechnology, 5(6):529-531.

47. Townsend, M. K., Devore, E. E., Resnick, N. M., \& Grodstein, F. (2013). Acidic fruit intake in relation to incidence and progression of urinary incontinence. International urogynecology journal, 24(4), 605-612.

48. The Compound 4-(2,6,6-Trimethyl-2-cyclohexen1-yl)-2-butanol, (2019). Retrieved 12/12/2019, from http://www.chemspider.com/ChemicalStructure.146024.html. 
49. Schweitzer, V. G. (1993). Ototoxicity of chemotherapeutic agents. Otolaryngologic Clinics of North America, 26(5), 759-789.

50. Castellanos, M., Power, J. B., \& Davey, M. R. (2010). Micropropagation of poinsettia by organogenesis. In Protocols for in vitro propagation of ornamental plants (pp. 67-75). Humana Press.

51. Lu, Z. Q., Guan, S. H., Li, X. N., Chen, G. T.,
Zhang, J. Q., Huang, H. L., ... \& Guo, D. A. (2008). Cytotoxic diterpenoids from Euphorbia helioscopia. Journal of natural products, $71(5)$, 873-876.

52. Kumar, P. P., Kumaravel, S., \& Lalitha, C. (2010). Screening of antioxidant activity, total phenolics and GC-MS study of Vitex negundo. African Journal of Biochemistry Research, 4(7), 191-195. 